\title{
High Interval Data Type
}

National Cancer Institute

\section{Source}

National Cancer Institute. High Interval Data Type. NCI Thesaurus. Code C95662.

A data type comprised of a set of consecutive high values of an ordered base data type. 